\title{
UPAYA MEWUJUDKAN JIWA KEWIRAUSAHAAN MAHASISWA MELALUI KEGIATAN MAGANG USAHA PADA KOPERASI SYARIAH KANINDO DAU MALANG
}

\author{
Dra .Uci Yuliati, M.M ${ }^{1)}$
}

\section{Ringkasan}

Keberadaan dunia pendidikan tinggi yang berperan pula memikirkan perkembangan koperasi dengan prinsip syariah yang ada di masyarakat melalui partisipasi aktif mahasiswa untuk mengenaldan memahami langsung tentang pengelolaan koperasi syariah seiring dengan perkembangan industri asa perkembangan yang berwawasan Islami mutlak untuk harus ditumbuhkembangkan. Magang kewirausahaan pada lembaga keuangan syariah (KANINDO) bertujuan untuk memberikan pengalaman praktis maupun pengembangan wawasan kewirausahaan kepada mahasiswa dengan cara melibatkannya sebagai bagian wilayah pada suatu usaha bisnis yang mencakup kegiatan pemagangan managemen usaha perkoperasian mulai dari pelayanan jasa simpan pinjam kepada nasabah, pengolahan data hingga sampai pada strategi pemasaran jasa keuangan.

Sebelum dan sesudah mengikuti pemgangan mahasiswa semangat mengikuti kegiatan karena kegiatan seperti ini masih belum di dapatkan ketika mengikuti kuliah, masiswa lebih termotivasi dalam berwira usaha dan meningkatnya kemandirian serta keberanian berkomunikasi, terbuka wawasan dalam mengelola diri sendiri maupun berkomunikasi dengan berbagai pihak, terbuka jalin kerjasama yang saling menguntungkan antara PT dan perusahaan mitra.

Guna meningkatkan kemajuan kegiatan magang dan kegiatan akademik secara keseluruhan agar dapat meningkatkan ketrampilan dan kemampuan bagi mahasiswa peserta maka peserta dapat melakukan kerjasama pihak-pihak mitra seperti koperasi syariah dan sekaligus dapat melakukan penelitian tentang kewirausahaan untuk tugas akhirnya.

1) Staff Pengajar Fakultas Ekonomi 


\section{A. PENDAHULUAN \\ 1.Pemikiran Yang Mendasari Kegiatan Magang}

Dalam sistem perkoperasian di Indonesia telah dikembangkan model koperasi dengan menggunakan prinsip syariah. Menurut data kementrian koperasi dan UKM, jumlah koperasi syariah kurang lebih sekitar 2.700 yang tersebar di seluruh pelosok tanah air. Dimana dalam pendiriannya juga diberikan ketentuan tentang penyetoran modal awal minimal $\mathrm{Rp}$ 15 juta untuk koperasi primer dan Rp 50 juta untuk koperasi sekunder. Layaknya bank, koperasi jasa keuangan syariah dan unit jasa keuangan syariah diperkenankan menghimpun dana anggota baik tabungan dan simpanan berjangka dengan akad mudharabah dan wadiah, serta menyalurkannya dalam pembiayaan mudharabah, musyarakah, murabahah, salam, istisna, ijarah, dan alqaradh.

Keberadaan dunia Pendidikan Tinggi yang merupakan suatu lembaga ilmiah ikut terpanggil dalam memahami dan mengikuti perkembangan perkoperasian (dengan prinsip syariah), guna menambah wawasan bagi kepentingan pengembangan ilmu pengetahuan dan aplikasi yang dapat diterapkan kepada masyarakat melalui tenaga pengajar dan anak didiknya (mahasiswa). Dengan demikian sudah saatnya peran lembaga ilmiah ikut serta memikirkan keberadaan perkembangan koperasi dengan prinsip syariah yang ada di masyarakat melalui partisipasi aktif mahasiswa untuk dapat mengenal langsung tentang sistem perkoperasian syariah.
Mahasiswa perlu memiliki pengalaman praktis tentang pengelolaan koperasi syariah seiring dengan perkembangan industri jasa perbankan yang berwawasan islami.

Krisis ekonomi secara nyata telah menyebabkan jatuhnya ekonomi nasional khususnya usaha-usaha skala besar pada semua sektor termasuk industri, jasa dan perdagangan. Dampak nyata berikutnya adalah peningkatan jumlah pengangguran secara signifikan, dimana sampai akhir tahun 2003 tercatat 11,4 juta jiwa (BPS), dengan pertumbuhan industri hanya mencapai 3,41\%. Apabila dicermati secara rinci ternyata pada masa krisis ekonomi justru yang dapat bertahan hidup adalah sektor usaha mikro yang ditopang dengan sistem perkoperasian baik di daerah pedesaan maupun perkotaan. Selanjutnya semakin banyak tumbuh dan berkembang model-model koperasi, salah satu model koperasi yang terkenal adalah dengan menggunakan sistem islami (prinsip syariah).

Berdasarkan fakta-fakta tersebut diatas memberikan indikasi bahwa setiap lulusan Perguruan Tinggi penting dan perlu diarahkan pada upaya dan realisasi pengembangan budaya kegiatan usaha mandiri melalui pengembangan pengetahuan tentang pengelolaan koperasi khususnya dengan prinsip syariah. Dengan adanya kegiatan ini diharapkan dapat menjadikan mahasiswa mengetahui dan mendalami serta dapat menerapkan model usaha keuangan dengan prinsip syariah. Selanjutnya mahasiswa dapat memiliki pengalaman praktis dalam pengelolaan 
koperasi syariah dan dapat menumbuh kembangkan jiwa kewirausahaannya. Pemilihan pada usaha koperasi syariah ini, karena selain sebagai lembaga keuangan Islami (Koperasi KANINDO) yang kantor pusatnya di daerah perbatasan kabupaten Malang dan Kota Batu, juga karena usaha ini sudah berhasil mengembangkan operasional usahanya dimulai dari kondisi yang sederhana (modal kecil) hingga berkembang memiliki 3 (tiga) cabang di daerah Kabupaten Malang (Wajak, Wonosari, dan Pujon). Lembaga ini memiliki usaha pokok jasa pelayanan simpan pinjam dan toko yang menyediakan berbagai macam kebutuhan pokok serta dipercaya sebagai lembaga yang menyalurkan dana bantuan pembangunan perumahan bagi masyarakat kecil.

\section{Kondisi Mahasiswa Pada Universitas Muhammadiyah Malang}

Mahasiswa sebagai pengguna jasa pelayanan pendidikan dan pengajaran pada saat ini tidah cukup hanya memahami teori yang diperoleh di bangku kelas, dipelajari di perpustakaan, di download dari internet saja. Namun mahasiswa sangat perlu memiliki pengalaman praktek di lapangan untuk membuktikan apakah teori yang dipelajari benar-benar dapat digunakan.

Mahasiswa pada universitas Muhammadiyah Malang juga telah banyak terlibat pada berbagai kegiatan kreativitas mahasiswa yang mendorong mahasiswa memiliki pengalaman praktek. Secara umum sarjana lulusan perguruan tinggi pada era globalisasi, saat ini dituntut tidak hanya menguasai teori saja namun mampu praktek di tempat kerja nanti. Oleh karena itu Universitas Muhammadiya telah menyediakan sarana dan prasaran guna menjadi wadah mahsiswa memiliki pengalamn praktek. Selain kegiatan magang yang dibangun melalui kerjasama antara perguruan tinggi dengan berbagaipihak di luar kampus, mahasiswa juga memperoleh kesempatan magang ditempat sendiri (unit-unit) sebagai mahasiswa part-timer workers.

\section{Tujuan Program}

Secara umum tujuan magang kewirausahaan (MKU) adalah memberikan pengalaman praktis maupun pengembangan wawasan kewirausahaan kepada mahasiswa dengan cara melibatkan mereka sebagai bagian intergral pada suatu usaha (bisnis) tersebut, yaitu bagaimana belajar melakukan pengelolaan/manajemen usaha perkoperasian mulai dari pelayanan jasa simpan pinjam kepada nasabah, pengolahan data hingga sampai pada strategi pemasaran jasa keuangannya.

Adapun yang menjadi tujuan dari MKU ini adalah :

a. Mewujudkan jiwa wirausaha bagi mahasiswa di lingkungan Perguruan Perguruan Tinggi khususnya Universitas Muhammadiyah Malang.

b. Membina kemandirian dan kemampuan kewirausahaan mahasiswa sebagai calon lulusan Perguruan Tinggi.

c. Menambah pengetahuan tentang perkoperasian dan usaha lembaga keuangan syariah baik dari aspek keilmuan, ketrampilan 
maupun pengalaman praktis dalam menjalankan suatu usaha jasa (services).

d. Meningkatkan pengetahuan dan strategi berusaha khususnya pada lembaga keuangan islami (koperasi syariah).

e. Menciptakan Lembaga Ekonomi Produktif (LEP) atau "bussiness center" bagi para peserta program dan secara berkelanjutan sebagai wadah bagi mahasiswa maupun calon lulusan di Universitas Muhammadiyah Malang, untuk mengembangkan budaya $\mathrm{k}$ e w i r a u $\mathrm{s}$ a $\mathrm{h}$ a a $\mathrm{n}$ (enterpreneurship culture).

\section{Target Luaran}

Target luaran yang ingin dicapai antara lain adalah:

1. Untuk memperoleh tampat Magang Kewirausahaan (MKU) bagi mahasiswa secara periodik.

2. Dapat mengembangkan jiwa kewirausahaan bagi generasi muda khususnya mahasiswa yang memiliki dasar pendidikan tinggi.

3. Adanya kerjasama dimana masingmasing pihak dapat decara matang saling menyesuaikan sehingga tercipta kompentensi masing-masing yang saling menguntungkan

\section{Indikator Keberhasilan}

Adapun indikator keberhasilan kegiatan magang kewirausahaan berdasarkan pengamatan terhadap peserta magang meliputi:

1. Terbentuknya minimal $40 \%$ mahasiswa peserta magang dapat menekuni bidang usaha yang sama khususnya dibidang keuangan syariah (koperasi/BMT).

2. Hubungan kerjasama yang lebih baik dengan mitra usaha yang dijadikan obyek magang bagi mahasiswa untuk program magang berikutnya.

3. Laporan magang kewirausahaan (MKU) mahasiswa tentang aktivitas yang dilakukan selama mengikuti magang dapat menjadi pengalaman empiris (pengelolaan usaha, pelayanan simpan pinjam,, pengolahan data, dan analisa usaha) , serta strategi pengembangannya untuk menjadi bekal berwirausaha.

4. Mahasiswa peserta magang dapat memahami permasalahanpermasalahan yang terjadi dalam aktivitas pengelolaan usaha sehingga menjadi lebih terlatih dalam memecahkan masalah khususnya di sektor keuangan.

5. Mahasiswa memiliki kemampuan dalam memberikan layanan jasa keuangan syariah, memiliki kemampuan mengambil keputusan, memiliki keberanian menaggung resiko, memiliki kemampuan komunikasi dan mempromosikan jasa keuang syariah di wilayah sekitar kampus maupun di daerah tempat tinggal masing-masing. 
6. Dapat menjadi obyek penelitian bagi mahasiswa untuk menyelesaikan studi khususnya dalam menyelesaikan tugas akhir (membuat skripsi).

\section{B. PELAKSANAAN KEGIATAN \\ 1. Analisis Situasi Mahasiswa Peserta Magang}

Mahasiswa peserta magang adalah mahasiswa UMM yang aktif atau memiliki keinginan untuk menambah pengetahuan tentang berwirausaha dan minimal sudah menempuh 100 SKS. Dengan demikian mahasiswa diharapkan sudah dapat memahami tentang etika dan pola berwirausaha serta memiliki kemampuan beradaptasi secara langsung. Sehingga dari keilmuan yang telah mereka pelajari diterapkan dalam bentuk usaha yang nyata, dan diharapkan juga adanya muncul inovasi, kreativitas, dan jiwa berwirausaha dikalangan mahasiswa peserta magang.

Mahasiswa peserta magang kewirausahaanpada Koperasi Agro Niaga Indonesia .(KANINDO)berjumlah 13 orang. Namun ada seorang yang mengundurkan diri karena alasan sakit. Peserta magang ditempatkan pada dua lokasi kantor yang berbeda yaitu di daerah Wagir dan Dau. Hal ini karena adanya kesepakatan antara pihak pimpinan KANINDO dengan ketua pelaksana agar mahasiswa memiliki pengalaman tidak hanya di daerah perkotaan namun juga pengalaman di daerah pinggiran kota atau pedesaan. Sebanyak 6 peserta magang ditempatkan di Kantor pusat Dau dan 7 orang peserta ditempatkan di Wagir. Secara terperinci mahasiswa peserta dapat dibedakan menurut jenis kelamin, angkatan masuk, alasan mengikuti magang dan pengalaman wirausaha.

\subsection{Peserta Menurut Jenis Kelamin}

Dari 13 peserta magang terdiri dari 7 orang mahassiswa dan 6 orang mahasiswi. Walaupun pada proses pendaftaran terdapat mahasiswi yang lebih banyak mendaftar ternyata yang diterima dan bersedia mengikuti kegiatan magang lebih banyak mahasiswa. Jumlah tersebut dapat dilihat pada tabel berikut.

Tabel 1. Peserta Magang Menurut Jenis Kelamin

\begin{tabular}{|l|l|l|}
\hline Jenis Kelamin & Jumlah & Persentase \\
\hline Laki-laki & 7 & 53,85 \\
\hline Perempuan & 6 & 46,15 \\
\hline Jumlah & 13 & 100,00 \\
\hline
\end{tabular}

\subsection{Peserta Menurut Angkatan}

Peserta magang sebanyak 13 orang tidak berasal dari satu angkatan yang sama namun dari berbagai angkatan dan jurusan manajemen, akuntansi dan D3 perbankan. Peserta magang berdasarkan angkatan dapat dilihat pada tabel berikut. Peserta magang terbanyak berasal dari angkatan 2007, sebanyak 6 orang (46,15\%), angkatan 2006 sebanyak 2 orang (15,38\%), angkatan 2005 sebanyak 4 orang (30,76\%), dan angkatan 2004 hanya seorang $(7,61 \%)$.

Tabel 2. Peserta Magang Menurut Angkatan

\begin{tabular}{|l|l|l|}
\hline Angkatan & Jumlah & Persentase \\
\hline Angkatan 2004 & 1 & 7,69 \\
\hline Angkatan 2005 & 4 & 30,77 \\
\hline Anglkatan 2006 & 2 & 15,39 \\
\hline Angkatan 2007 & 6 & 46,15 \\
\hline Jumlah & 13 & 100,00 \\
\hline
\end{tabular}

Sumber. Formulir Pendaftaran 
Dari tabel 2 dapat dilihat bahwa mahasiswa peserta terbanyak berasal dari angkatan 2007 dan 2005. Sebanyak empat orang yang berasal dari angkatan 2005 sebanyak tiga orang sudah berhasil menyelesaikan studi seiring dengan kegiatan magang yang mereka ikuti. Seorang mahasiswa masing sedang menyelesaikan studi dan melakukan penelitian pada lembaga tempat magang pada saat laporan ini dibuat.

\subsection{Peserta Menurut Harapan}

Mahasiswa calon peserta magang sebelum mengikuti magang diwajibkan mendaftar dan mengisi formulir pendaftaran. Berdasarkan harapan yang mereka tuliskan pada formulir tersebut ternyata hanya sedikit sekali (orang atau 23,07\%) yang memiliki harapan untuk melakukan wirausaha. Sebagian besar mereka berkeinginan memperoleh pengalaman ( sebanyak 6 orang atau 46,15 \%) dan menambah ilmu (sebanyak 4 orang atau 30,76\%). Sedikitnya jumlah mahasiswa yang berharap dapat berwirausaha tersebut dapat dikatakan semakin pentingnya dilakukan kegiatan magang agar jiwa kewirausahaanya semakin terasah dan tumbuh berkembang. Secara terperinci harapan mahasiswa dapat dilihat pada tabel berikut.

Tabel 3. Peserta Magang Menurut Harapan (alasan)

\begin{tabular}{|l|l|l|}
\hline Harapan & Jumlah & Persentase \\
\hline Ingin Berwirausaha & 3 & 23,07 \\
\hline Memperoleh Pengalaman & 6 & 46,15 \\
\hline Menambah Ilmu & 4 & 30,76 \\
\hline Jumlah & 13 & 100,00 \\
\hline
\end{tabular}

Berdasarkan tabel di atas sebagian besar mahasiswa berharap mengikuti kegiatan magang kewirausahaan ini untuk memperoleh pengalaman, khususnya bekerja pada lembaga keuangan syariah.

\subsection{Peserta Menurut Pengalaman Wirausaha}

Mahasiswa peserta magang yang lolos seleksi kegiatan magang ini ada yang sudah memiliki pengalaman berwirausaha seperti berjualan pulsa, berjualan pakaian, berjualan makanan kecil. Namun sebagian mereka belum memiliki pengalaman sama sekali. Oleh karena itu dapat dibedakan mahasiswa yang sudah berpengalaman berwirausaha dan belum berpengalaman sebagaimana dapat dilihat pada tebel berikut.

Tabel 4. Mahasiswra Peserta Magang Menurut Pengalaman

\begin{tabular}{|l|l|l|}
\hline Pengalaman & Jumlah & Persentase \\
\hline $\begin{array}{l}\text { Sudah pengalaman } \\
\text { Berwirausaha }\end{array}$ & 6 & 46,15 \\
\hline $\begin{array}{l}\text { Belum pengalaman } \\
\text { Berwirsusaha }\end{array}$ & 7 & 53,85 \\
\hline Jumlah & 13 & 100 \\
\hline \multicolumn{2}{|l|}{ Sumber: Formulir Pendaftaran }
\end{tabular}

Bagi mahasiswa yang sudah berpengalaman berwirausaha, keikutsertaannya pada kegiatan magang ini akan semakin menambah keanekaragaman pengalaman dalam berwirausaha. Sedangkan bagi yang belum memiliki pengalaman, keikutsertaan pada kegiatan ini sangat bermanfaat sebagai ajang meningkatkan budaya kewirausahaan sehingga jiwa kewirausahaannya dapat meningkat, sekaligus memiliki pengalaman

Sumber. Fonmulir Pendaftaran 
praktek dan berinteraksi dengan banyak pihak.

\section{Analisis Situasi Koperasi Syariah KANINDO}

Tempat kegiatan magang usaha adalah Lembaga Keuangan Koperasi Argo Niaga Syariah “KANINDO” yang berdiri sejak tahun 1998. Jarak kantor pusatnya dengan kampus UMM kurang lebih $2 \mathrm{Km}$ ke arah barat utara. Lembaga keuangan syariah ini memiliki 3 kantor cabang di wilayah Kabupaten Malang (Kecamatan wajak, Kecamatan Wono Sari, dan Kecamatan Pujon). Pertimbangan dipilihnya lokasi tersebut, karena adanya potensi pengembangan usaha baru dibidang perkoperasian (dengan model BMT, maupun Koperasi mandiri dengan prinsip Syariah).

Lembaga keuangan Syariah KANINDO dikatakan layak karena dengan 3 tempat usaha sangat memungkinkan menjadi tempat magang yang memadai. Mahasiswa peserta magang dapat memperoleh kesempatan dan pengalaman yang lebih banyak Pada kesempatan magang kali ini, pimpinan KANINDO hanya membagi mahasiswa peserta magang menempati dua lokasi saja yaitu di kantor Dau dan di kantor Wagir, kecamatan Wonosari. Sejumlah 13 mahasiswa peserta magang sebanyak 7 orang mengikuti magang di kantor Wagir dan sebanyak 6 orang di kantor Dau.

\subsection{Latar Belakang Tempat Magang}

Pada saat perekonomian mulai mengalami krisis ekonomi dimana usaha pada sektor riil mengalami kemerosotan yang luar biasa, pada saat itulah bermunculan usaha jasa sebagai produk yang mulai diminati dan mulai berkembang. Usaha Jasa keuangan syariah KANINDO yang didirikan pada saat krisis tersebut sebagai bukti adanya kemauan sekelompok orang yang memulai usaha karena minimnya lapangan usaha di sektor riil. Kenyataan pada saat itu banyak perusahaan besar melakukan Pemutusan Hubungan Kerja (PHK) sehingga banyak terjadi pengagguran dimana-mana. Tidak demikian pada perusahaan kecil yang sudah terbiasa merangkak dalam operasinya. Bahkan KANINDO mulai didirikan dalam rangka menangkap peluang membuka lapangan kerja. Adapun yang mendorong didirikannya usaha bidang keuangan saat itu antara lain adalah:

- Tekad dan keberanian para pendiri

- Keberanian pendiri dalam memulai usaha

- Keberanian pendiri untuk menganggung resiko bisnis

- Keuletan dan ketekunan para pendiri

- Adanya peluang bisnis sektor finansial

- Jiwa Kewirausahaan pendiri yang memadai

Adapun kondisi tempat magang KANINDO dapat dilihat pada tabel sebagai berikut. 
Tabel 5. Kondisi Tempat Magang (Mitra Usaha)

\begin{tabular}{|c|c|c|}
\hline No. & URAIAN & KETERANGAN \\
\hline 1. & Keadian Umum Mitra Usaha & $\begin{array}{l}\text { Usaha Lembaga Keuangan Syariah } \\
\text { (Koperasi simpan pinjam) }\end{array}$ \\
\hline 2. & Nama Mitra Usaha & Lembaga Keuangan Syariah (KANINDO) \\
\hline 3. & Tahun Pendirian Usaha & Tahun 1998 \\
\hline 4. & Jumlah Tenaga Keja & $\begin{array}{l}31 \text { karyawan ; } \\
\text { - Kantor Puast (Kec. Dan) } 13 \text { orang } \\
\text { - KC. Kec. Wajak } 6 \text { orang } \\
\text { - KC. Kec. Wonosari } 6 \text { orang } \\
\text { - KC. Kec. Pujon } 6 \text { orang }\end{array}$ \\
\hline 5. & Bidang Uasha & $\begin{array}{l}\text { 1. Jasa Keuangan Syariah } \\
\text { 2. Pertokoan } \\
\text { 3. Pembiayaen Perumahan }\end{array}$ \\
\hline 6. & Fasilitas /Komunikasi & Tlp. (0341) 464444 - 464445 \\
\hline 7. & Alamat Usaha (Kantor Pusat) & In. Raya Sengkaling 293 DAU Malang \\
\hline
\end{tabular}

Usaha jasa keuangan KANINDO ini merupakan hasil kerja dari para pendiri yang memiliki jiwa kewirausahaan yang tangguh yang selaluberupaya untuk mengembangkan usahanya walaupun di era krisis ekonomi. Walaupun para pendiri tidak berasal dari lulusan Fakultas Ekonomi, namun kemampuan manajerialnya dapat dicontoh. Hanya beberapa saja yang memiliki latar belakang keilmuan yang relevan. Selanjutnya jumlah karyawan yang memiliki keahlian keuangan syariah semakin meningkat karena adanya pengembangan karyawan yang berupa pelatihan dan kursus pada lembagan keuangan Syariah BMT.
Seiring dengan kemajuan dan pesatnya perkembangan jasa keuangan usaha KANINDO semakin banyak membutuhkan karyawan. Sampai saat ini jumlah karyawan sebanyak 31 orang yang ditempatkan pada tiga lokasi kantor KANINDO. Adanya keuletan para karyawan tersebut dalam mengembangkan usahanya sehingga asset KANINDO juga mengalami kemajuan pesat, jumlah nasabah juga semakin meningkat dari tahun ke tahun. Bahkan KANINDO dipercaya pemerintah untuk menyalurkan bantuan uang untuk pembangunan perubahan bagi mayarakat yang kurang bebruntung. 
Banyaknya karyawan dan lokasi kantor tersebut dapat menjadi pendorong dan teman kerja bagi mahasiswa peserta magang. Dengan demikian mahasiswa dapat memperoleh bimbingan dari mereka di lapangan. Pihak KANINDO telah menugaskan seorang karyawan untuk mengkordinir para peserta magang sehingga hubungan monitoring pelaksanaan kegiatan magang dapat berjalan dengan lancar

Bidang pekerjaan yang ditekuni mahasiswa sebagian besar adalah jasa pelayanan keuangan dan melakukan promosi dan presentasi ke berbagai lembaga seperti sekolah, kelompok pengusaha, petani, dan ibu-ibu kelompok pengajian dan PKK di daerah pedesaan maupun perkotaan. Selain itu mahasisiswa juga melakukan evaluasi kelayakan pemberian kredit (survey) kepada para calon penerima kredit dari KANINDO.

\subsection{Potensi Ekonomi dan Pemasaran Jasa Keuangan}

Potensi ekonomi KANINDO dapat dilihat dari produk jasa pelayanan yang ditawarkan dan kemampuan menciptakan usaha-usaha baru. Jasa pelayanan simpan pinjam yang berdasarkan prinsip keuangan syariah menjadi keunggulan yang dapat dikembangkan mengingat semakin meningkatnya kesadaran dan pengetahuan masyarakat pada jasa lembaga keuangan syariah. Dengan adanya sistem bagi hasil yang didasarkan pada prisnsip syariah, para nasabah merasakan lebih diperhatikan $\begin{array}{ccc}\text { Kegiatan utama } & \text { KANINDO } \\ \text { adalah menghimpun dana dari }\end{array}$ mamsyarakat dan menyalurkan kembali kepada masyarakat dalam berbagai bentuk pembiayaan. Adapun bentuk simpanan/ tabungan antara lain berupa tabungan harian, tabungan walimah, tabungan aqiqah, tabungan pendidikan, tabungan haji, simpanan perumahan, deposito. Sedangkan pembiayaan yang ditawarkan adalah pembiayaan mudharobah, musyarakah dan murabahah.

Pemasaran jasa keuangan dilakukan kepada semua lapisan masyarakat. Dalam melakukan pemasaran jasa keuangan, pihak KANINDO melakukan dengan berbagai strategi, salah satunya melakukan promosi dengan melakukan berbagai kegiatan seperti nonton bareng di sekolah-sekolah. Kegiatan ini cukup efektif mengingat sekolah adalah lembaga pendidikan yang peserta didiknya dapat dimotivasi untuk melakukan tabungan pendidikan, yang merupakan jenis simpanan yang ditawarkan.

Setelah kurang lebih 11 tahun melakukan operasi usahanya, manajemen KANINDO dapat dikatakan semakin baik. Hal ini dapat dilihat dari jumlah karyawan yang sudah mencapai 31 orang. Dengan sumberdana yang mandiri, dapat dicapai asset sekitar 7 miliar rupiah. Dengan dikelola karyawan sebanyak itu, daerah pemasaran sudah meliputi daerah sekitar kampus, kota dan kapupaten Malang. Dengan pengguna jasa yang terdiri dari para mahasiswa, dosen, masyarakat pemilik usaha mikro, rumah tangga. 


\subsection{Struktur Organisasi KANINDO}

Struktur organisasi adalah mekanisme untuk mencapai tujuan koperasi yang telah ditetapkan, dimana diletakkan pembentukan pekerjaan dan unsur-unsur yang ada menurut suatu sistem yang cocok dangan maksud tujuan organisasi. Tanggung jawab masing-masing fungsi yang semuanya terlibat dan dilaksanakan secara konsekuen didalam penerapan seharihari. Agar kegiatan organisasi Unit Jasa Keuangan Syari'ah Kanindo Malang dapat berjalan dengan baik dan lancar, maka haruslah jelas dan tegas dalam pembagian tugas, wewenang dan tanggung jawab dalam pelaksanaan masing-masing bagian. Adapun struktur organisasi di Unit Jasa Keuangan Syari'ah Kanindo Malang dapat dilihat pada gambar berikut ini:
Gambar 1.

Bentuk Struktur Organisasi dan Personalia Unit Jasa Keuangan Syari'ah Kanindo Malang

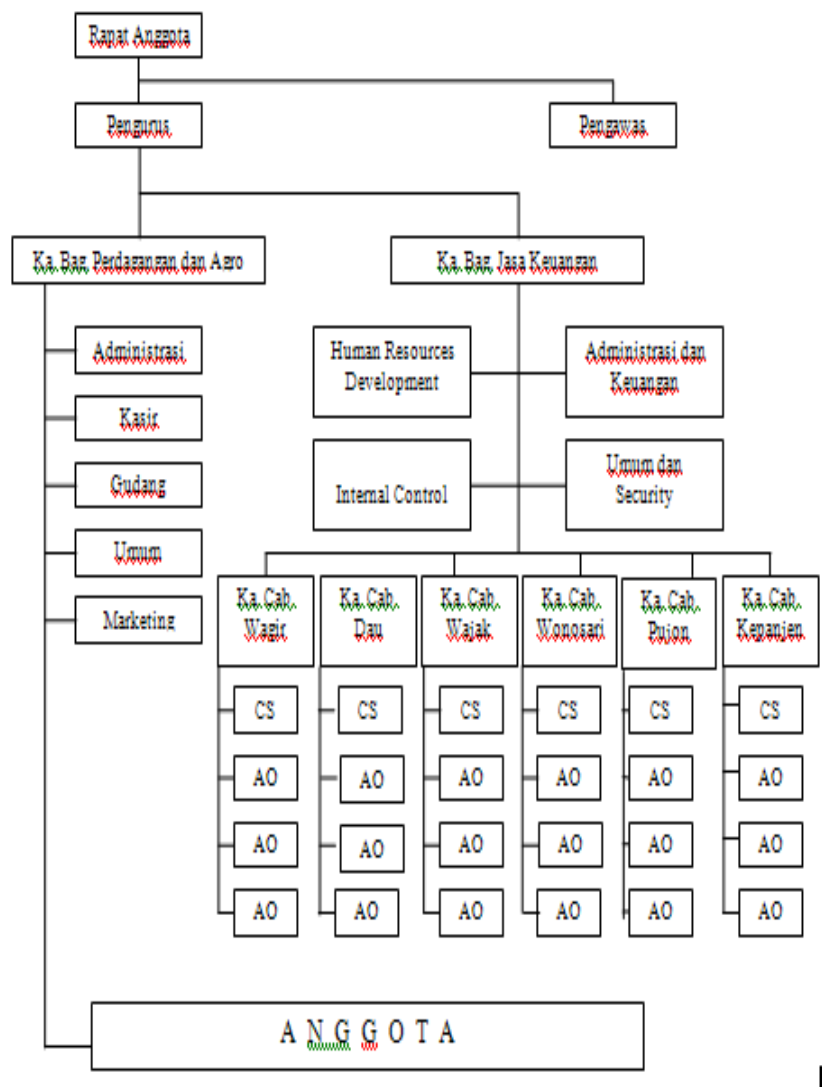

Sumber: Unit Jasa Kengan Sxri ha Karindo Malang

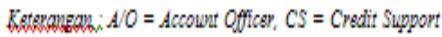

Berdasarkan struktur organisasi yang ada pada Unit Jasa Keuangan Syari'ah Kanindo Malang tersebut dapat dijelaskan sebagai berikut 


\section{Pelaksanaan Kegiatan dan Pola Evaluasi Proses Pelaksanaan \\ Magang}

Kegiatan ini dilakukan denngan serangkaian kegiatan yang saling terkait. Kegiatan ini dimulai dengan menjalin hubungan dengan pihak KANINDO sebagai langkah awal untuk penjajagan kelayakan dan kesediaan KANINDO sebagai mitra magang mahasiswa. Juga dengan para ahli yang berkompeten memberikan pembekalan dan tempat pelatihan seperti laboratorium manajemen.

\subsection{Proses Pelaksanaan Kegiatan a.Penetapan Kerja Sama}

Setelah terjadi kesepakatan bekerjasama dengan pihak KANINDO, selanjutnya perlu dilakukan penetapan kerjasama dalam bentuk penandatanganan kesediaan kedua belah pihak untuk saling bekerja sama. KANINDO sebagai tempat magang bersedia melakukan pembimbingan dan pengarahan mahasiswa peserta magang dengan menyiapkan karyawan yang mengkoordinir dan mengarahkan mahasiswa. Usaha ini telah memiliki profesionalisme dalam bidang kerjanya, kegiatan usahanya jelas, berbadan hukum dan memiliki tujuan jelas serta memiliki prospek usaha yang baik sehingga layak menjadi tempat magang.

\section{b. Rekruitmen dan seleksi}

Seleksi administratif dilakukan untuk mengetahui profil mahasiswa peserta magang seperti asal jurusan, angkatan, jenis kelamin, pengalaman dan harapan magang. Kemudian Seleksi tes dan wawancara untuk memilih mahasiswa yang dapat mengikuti dari sisi kesiapan dan kemampuannya mengingat ada sebanyak 22 mahasiswa yang mendaftar untuk mengikuti magang. Namun hasil tes wawancara hanya 13 mahasiswa saja yang memenuhi syarat dan benar-benar siap serta memenuhi harapan KANINDO seperti :

- Mahasiswa Fakultas Ekonomi

- Telah mengikuti mata kuliah : pengantar Ekonomi, Manajemen, Kewirausahaan

- Memiliki motivasi kerja yang tinggi

- Mempunyai minat besar dalam berwirausaha

- Supel, mudah bergaul dan bekerjasama

- Berkelakuan baik.

\section{c. Pembekalan}

Hasil seleksi diambil 13 peserta magang untuk mengikuti pembekalan berbagai pengetahuan kewirausahaan dan pengetahuan tentang koperasi serta lembaga keuangan dalam bentuk syariah.

d. Pemberangkatan mahasiswa peserta kelokasi tempat Magang

Pemberangkatan mahasiswa magang dilakukan secara mandiri. Pihak KANINDO dan ketu pelaksana bertemu untuk serah terima mahasiswa sebagai peserta magang.

\section{e. Pemagangan mahasiswa}

Pelaksanaan kegiatan magang mahasiswa dilakukan selama satu setengan bulan, diawali pada bulan Juli sampai dengan pertengahan bulan Agustus 20009. Lamanya kegiatan magang ini disesuaikan 
dengan kesediaan dan kesiapan pihak

KANINDO dan ketersediaan dana dan

kegiatan kampus.

c. Evaluasi pelaksanaan magang

Pada tahap Evalusi ini bertujuan untuk menganalisis proses pelaksanaan magang secara bertahap sehingga jika ada hambatan ataupun permasalahan segera dapat dipecahkan.

d. Penyusunan laporan

Laporan kegiatan magang dilakukan secaraindividu dan kelompok mahasiswa. Kelompok mahasiswa yang ditempatkan di kantor pusat Du dan Kantor cabang Wagir.

e. Pembahasan Keberhasilan Magang

Tahap ini merupakan proses analisis, penilaian dan pembahasan keberhasilan kegiatan magang yang telah berlangsung selama 1,5 bulan sehingga dapat digunakan sebagai bahan evaluasi guna menentukan langkah berikutnya.

\section{f. Kesinambungan Kerjasama} Kesinambungan kerjasama dilakukan berdasarkan hasil evaluasi keberhasilan magang. Pihak KANINDO sangat berharap adanya mahsiswa magang yang dapat menjadi karyawan maupun dapat membuka usaha ketika mereka pulang ke daerah asal mereka.
Gambar. 2. Proses Pelaksanan Kegatan MKV

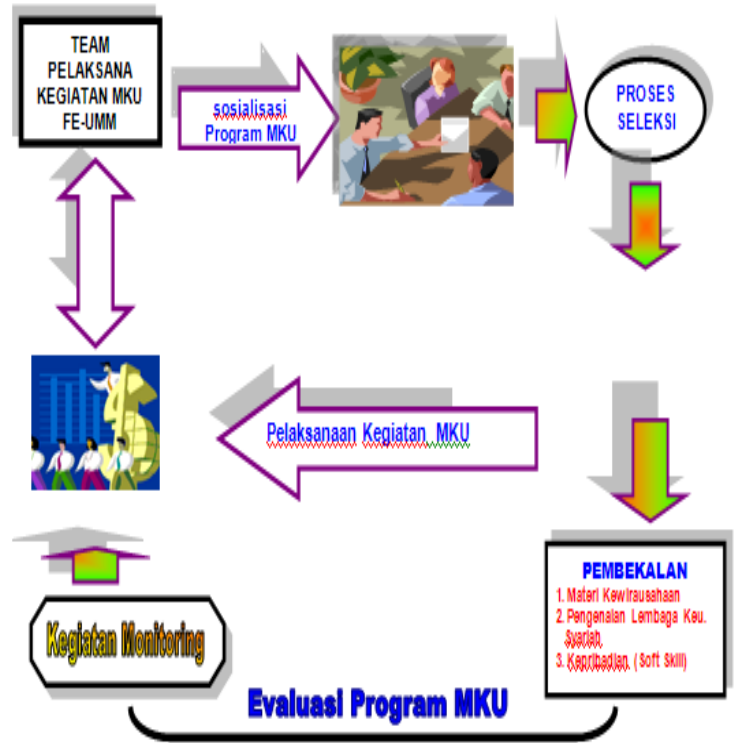

\section{EVALUASI DAN PEMBAHASAN} PELAKSANAAN KEGIATAN

\section{Evaluasi Pelaksanaan Kegiatan}

Pelaksanaan kegiatan magang

dilakukan secara berkala oleh pihak pelaksana dari dari Kanindo dan dari Tim Perguruan Tinggi. Evaluasi dan monitoring dilakukan untuk memperoleh gambaran tentang permasalahan mahasiswa peserta ketika mengikuti magang dan hasil pelaksanaan magang oleh mahasiswa. Kriteria penilaian evaluasi keaktifan mahasiswa meliputi kehadiran, ketrampilan dan kemampuan..

Secara keselurhan kehadiran mahasiswa dapat dikatakan disiplin, hanya ada satu mahasiswa yang tidak dapat mengikuti kegiatan magang sampai batas akhir waktu magang. Dilihat dari 
Jurnal Dedikasi Volume 7, Mei 2010

ketrampilan berkomunikasi, mahasiswa semakin trampil melakukan komunikasi dengan pihak nasabah, calon nasabah maupun dengan rekan kerja di kantor. Mahasiswa peserta magang juga memiliki kemampuan dalam pelayanan jasa keuangan, pelayanan dalam membantu nasabah yang akan mengajukan kredit.

Bagi mahasiswa peserta yang ditugaskan melakukan promosi tentang produk jasa keuangan syariah juga semakin memiliki kemampuan dalam memasarkan jasa simpan pinjam maupun kredit. Selain itu mahasiswa juga semakin meningkat kemampuannya dalam membangun kemandirian berusaha/berwirausaha. Secara terperinci manfaat kegiatan magang bagi mahasiswa, bagi mitra, perguruan tinggi dan masyarakat dapat dilihat pada uraian berikut.

\section{Pembahasan Manfaat}

Pelaksanaan Kegiatan

\subsection{Bagi Mahasiswa}

1) Peningkatan kompetensi, kemampuan dan daya saing calon lulusan.

2) Penajaman kompetensi produktif dengan ketrampilan wirausaha sesuai dengan bidang keahliannya.

3) Terbina bekerja mandiri dan tidak bersikap menunggu atau mencari pekerjaan kepada orang lain.

4) Mampu menciptakan lapangan kerja bagi dirinya dan masyarakat sekitarnya.
5) Mahasiswa memiliki ketrampilan komunikasi, pelayanan jasa dan survey kelayakan pemberian kredit.

6) Mahasiswa memiliki kemampuan dan keberanian dalam menghadapi permasalahan di lapangan.

7) Mahasiswa Lulusan menjadi lebih trampil dan berpengalaman.

8) Mahasiswa peserta memiliki kemampuan untuk mandiri dalam bekerja maupun bekerjasama dengan berbagai pihak.

\subsection{Bagi Mitra}

1) Terjadinya kerjasama sinergi antara dunia usaha (mitra usaha) dengan Perguruan Tinggi dalam upaya saling meningkatkan kinerja dan mutu produk/jasa/lulusan.

2) Terciptanya kerjasama sinergi dalam hal pengembangan usaha bagi mitra usaha dan pengembangan penelitian terapan bagi dosen dan mahasiswa peserta didik.

\subsection{Bagi Perguruan Tinggi}

1) Peningkatan kualitas fakultas / program studi dalam menghasilkan lulusan.

2) Meningkatkan jumlah lulusan yang bekerja secara mandiri.

3) Meningkatkan faktor kegunaan dari berbagai 
fasilitas/sarana-prasarana serta fasilitas pendukung lainnya dilingkungan Universitas Muhammadiyah Malang.

\subsection{Bagi Masyarakat}

Berkembangnya persepsi masyarakat tentang Pendidikan Tinggi di UMM yang semula hanya dianggap sebagai institusi pencipta tenaga kerja, menjadi institusi yang juga pencipta lapangan kerja melalui lulusannya.

3. Metode Analisis Masalah dan Pemecahannya Pada KANINDO 3.1. Masalah Perusahaan Dari hasil pengamatan yang dilakukan ternyata dalam pelaksanaan magang masih ditemui berbagai permasalahan yang terjadi pada tempat magang dan masih perlu dibenahi. Masalah yang terjadi antara lain :

- Belum adanya kejelasan pelaksanaan job deskripsi pada setiap bagian.

Kenyataan ada struktur organisasi dan dan tugas masing-masing bagian, namun demikian antar bagian masih saling bertukar pekerjaan sehingga karyawan seering tidak fokus pada satu pekerjaan yang semestinya menjadi keahliannya.

- Koordinasi antar kantor pusat dan kantor cabang belum optimal.
Adanya kantor pusat dan cabang yang letaknya berjauhan sudah tersedia sarana komunikasi tilpun kantor. Setiap karyawan juga memiliki telepon selular. Namun dalam pelaksanaan suatu kegiatan yang membutuhkan bantuan kantor pusat kurang terkoordinir dengan baik sehingga pelaksanaan kegiatan kantor cabang menjadi kurang optimal. Artinya apabila ada kegiatan yang bersamaan antara kantor cabang dan pusat sering kurang direncanakan juga,sehingga pada saat pelaksaan ketika membutuhkan peralatan seperti LCD, maka kantor cabang yang dinomorduakan.

- Keterbatasan sarana LCD sebagai alat bantu dalam melakukan promosi jasa keuangan syariah.

Keterbatasan LCD menjadi hambatan untuk majunya kegiatan promosi terutama di kantor cabang. Kebutuhan LCD kantor cabang sangat tergantung kantor pusat, sehingga jika kegiatan yang membutuhkan LCD bersammaan, kantor cabang mendahulukan kantor pusat. Namun jika ada perencanaan dan kordinasi 
yang baik semestinya ini

tidak perlu terjadi.

Penggunaan LCD harus

dijadwal secara bergiliran

antara kantor cabang dan pusat secara rutin.

\subsection{Pemecahan Masalah}

Kemajuan dan perkembangan perusahaan jasa keuangan syariah seperti KANINDO adalah terletak pada ketrampilan sumberdaya manusianya, terutama aspek ketelitian dan kerincian serta keramaha tamahan dalam pemberian pelayanan jasanya.

Dalam memecahkan permasalahan yang terjadi pada usaha jasa keuangan dapat dipetakan sebagai berikut.

\section{a). Struktur Organisasi}

Belum adanya struktur organisasi pada setiap kantor cabang dan job deskripsi yang terinci pada setiap bagian/ tingkatan struktur organisasi. Padahal adanya struktr organisasi dalam sebuah perusahaan harus menjadi acuan dalam pelaksanaan semua kegiatan/operasi yang ada, sehingga harus ada pada setiap kantor cabang.

Oleh karena itu untuk mengatasi masalah tersebut harus dibuat struktur organisasi yang harus dipasang pada setiap kantor cabang. Dengan struktur organisasi setiap ada kegiatan yang harus dikoordinasikan dengan kantor pusat akan lebih lancar. Karena orang-orang yang bertanggung jawab akan dengan mudah melakukan koordinasi dengan bagian terkait. Demikian juga akan memperjelas siapakah yang harus bertanggung jawab dan memiliki wewenang dalam pelaksanaan kegiatan.

Selain itu adanya struktur organisasi akan memperjelas alur komunikasi antar bagian. Kegiatan yang akan dilakukan juga dapat direncanakan dengan matang terlebih dahulu sehingga jadwal kegiatan antar kantor yang memerlukan kantor pusat tidak saling tumpang tindih dan dapat berjalan sesuai dengan yang telah direncanakan.

\section{b) Program Pelatihan dan Pengembangan Karyawan}

program pelatihan dan pengembangan karyawan dapat menjadikan adanya kurangnya pemahaman karyawan pada bidang pekerjaannya. Oleh karena itu untuk meningkatkan ketrampilan pelayanan perlu dilakukan pelatihan dan pengembangan secara rutin.

Pelatihan dan pengembangan yang sudah dilakukan harus diikuti dengan pelaksanaan kegiatan pengawasan terhadap pekerjaan karyawan agar dapat diketahui apakah pelaksanaan pekerjaan sudah sesuai dengan rencana atau belum. Selain itu evaluasi secara rutin juga perlu dilakukan agar dapat diketahui penerapan dari hasil pelatihan dan pengembangan apakah sudah 
Uci Yuliati.Upaya Mewujudkan Jiwa Kewirausahaan Mahasiswa

menjadikan karyawan semakin tinggi

ketrampilannya atau belum.

\section{PENUTUP}

Berdasarkan pada uraian diatas dapat ditetapkan beberapa kesimpulan dan saran sebagai berikut:

\section{Kesimpulan}

Kegiatan magang kewirausahaan (MKU) dapat mempercepat masa studi mahasiswa,sangat penting dalam meningkatkan kualitas lulusan suatu perguruan tinggi, meningkatkan kemampuan perilaku manajerial mahasiswa. meningkatkan perilaku soft-skill mahasiswa sehingga menjadikan mahsiswa lebih siap dalam memasuki dunia kerja serta mahasiswa dapat memiliki jiwa kewirausahaan yang semakin tangguh.

\section{Saran}

Perlu keberlanjutan kegiatan magang kewirausahaan yang dilaksanakan secara lebih terintegrasi dengan berbagai kegiatan akademik baik pengajaran dan penelitian sehingga dapat meningkatkan mutu lulusan

perguruan tinggi. 
Jurnal Dedikasi Volume 7, Mei 2010 